Diabetologia 10, 61-68 (1974)

(C) by Springer-Verlag 1974

\title{
Glucagon Immunoassay Using Polyethylene Glycol to Precipitate Antibody-Bound Hormone
}

\author{
J.C. Henquin, P. Malvaux and A.E. Lambert \\ Unité de Diabète et Croissance, University Hospital St. Pierre, Louvain, Belgium
}

Received: June 25, 1973, and in revised form: October 10, 1973

\begin{abstract}
Summary. The use of polyethylene glycol 6000 to separate free and antibody-bound ligand has been applied to the radioimmunoassay of glucagon. Equalization of protein content in all tubes before precipitation of the glucagon-antibody complex was required. Time between addition of the polymer and centrifugation had no detectable effect. Degradation of ${ }^{131}$ I-glucagon during incubation was best prevented by a combination of benzamidine $(5 \mathrm{mM})$ and Trasylol ${ }^{\circledR}(500 \mathrm{KIE} /$ tube). Sensitivity of the assay permitted discrimination of buffer or plasma samples $(100 \mu l)$ whose glucagon contents differed from $25 \mathrm{pg} / \mathrm{ml}$, under $100 \mathrm{pg} / \mathrm{ml}$, and $35 \mathrm{pg} / \mathrm{ml}$, under
\end{abstract}

$200 \mathrm{pg} / \mathrm{ml}$. Reproducibility was $9.5 \%$ (coefficient of variation) for plasmas with glucagon concentrations ranging from 100 to $300 \mathrm{pg} / \mathrm{ml}$. Recovery of exogenous glucagon added to plasma was satisfactory. Measurement of glucagon was possible in fasting plasma samples diluted up to $1 / 8$. The separation method described appears to be easy and reliable, especially when large numbers of samples are routinely handled.

Key words: Glucagon, radioimmunoassay, polyethylene-glycol, proteolytic enzymes inhibitors.
Since the initial description of glucagon immunoassay by Unger et al. [34, 35], a number of improvements have been introduced (see ref. 21 for a review). Besides utilization of antisera specific for pancreatic glucagon and adequate prevention of labelled glucagon degradation during incubation, most of the refinements of the technique are dealing with the separation of free and antibody-bound hormone.

Three major groups of methods are available. Separation may be carried out by paper chromatography $[3,19,27,34]$. The glucagon-antibody complex may be precipitated by $\mathrm{Na}_{2} \mathrm{SO}_{4}$ [14], a second antibody $[15,29]$, or ethanol $[10,16]$. Finally, free glucagon may be selectively adsorbed by an ionic exchange resin [38], cellulose powder [26] or dextran-coated charcoal [2, $20]$.

Recently, the use of polyethylene glycol 6000 (PEG) to precipitate antibody-bound ligand from the free compound was reported by Desbuquois and Aurbach [8]. So far, this separation technique has been successfully used in radioimmunoassays of insulin, growth hormone, parathyroid hormone [8], arginine-vasopressin $[8,13]$, cyclic AMP $[8,28]$, angiotensin $I$ and digo$\operatorname{xin}[6]$.

The purpose of this report is to describe the application of this new separation method to glucagon immunoassay.

\section{Materials}

\section{Buffers}

A sodium phosphate buffer (0.04 M, $\mathrm{pH} 7.4$ ) with $0.1 \mathrm{~g}$ bovine serum albumin $/ 100 \mathrm{ml}$ and $0.02 \mathrm{~g}$ Merthiolate ${ }^{\circledR} / 100 \mathrm{ml}$ (buffer $G A$ ) was used for the dilution of labelled glucagon. Working standards were prepared and unknown diluted (when required) in the same buffer supplemented with $\mathrm{NaCl} 6 \mathrm{~g} / 100 \mathrm{ml}$ (buffer $G B$ ). At the time of the assay, Trasylol ${ }^{\circledR}$ was added to buffer GA (buffer GA-TRAS) to reach the concentration of $5000 \mathrm{KIE} / \mathrm{ml}$. This buffer was used to dilute the antiserum or for the blanks (see assay procedure).

\section{Glucagon Standards}

Monocomponent pork glucagon (Novo, lot MC 6770) was used as standard. Stock solutions of $50 \mathrm{ng} / \mathrm{ml}$ were stored in aliquots at $-25^{\circ} \mathrm{C}$. Each aliquot was thawed once for the preparation of the working standard solutions $(0,50,100,200,400,600,1000$ and $2000 \mathrm{pg} / \mathrm{ml}$ ) by volumetric dilution with buffer GB.

\section{Labelled Glucagon}

${ }^{131}$ I-glucagon was purchased from the Centre National de Transfusion Sanguine, Paris. The specific activity varied from 600 to $850 \mu \mathrm{Ci} / \mu \mathrm{g}$. Frozen on arrival, labelled glucagon was thawed immediately prior to use and diluted with buffer GA, to provide a solution of $250 \mathrm{pg}{ }^{131}$ I-glucagon $/ \mathrm{ml}$.

\section{Anti-Glucagon Serum}

Anti-pork glucagon rabbit serum K814 (from L.G. Heding, Novo Research Institute, Copenhagen, Denmark) was used. It is considered as specific for pancreatic glucagon [17].

\section{5. $P E G$ Solutions}

A $23.75 \%(w / w)$ solution of PEG (providing a $12.5 \%$ final concentration in assay tubes) was freshly prepared before use by dissolving the polymer in distilled water pre-chilled to $4^{\circ} \mathrm{C}$. After dissolution, continuous stirring was not required to keep homogeneity. 


\section{Reagents}

Salts of analytical grade used for buffers, trichloracetic acid (TCA) and PEG 6000 were purchased from Merck A.G. (Darmstadt, Germany), benzamidine hydrochloride from Schuchardt (München, Germany), bovine serum albumin from Poviet (Amsterdam, Netherlands), Merthiolate ${ }^{\circledR}$ from Eli Lilly and Co. (Indianapolis, U.S.A.), epsilon-aminocaproic acid (EACA) from Koch-Light Lid. (Colnbrook, England) and heparin from F. Hoffman-La Roche and Co. Ltd. (Basel, Switzerland). Trasylol ${ }^{\circledR}$ powder $(5000 \mathrm{KrE} / \mathrm{mg})$ was obtained from Bayer A.G. (Leverkussen, Germany).

\section{Methods}

\section{Blood Collection}

$10 \mathrm{ml}$ venous blood were collected into $100 \mu \mathrm{l}$ buffer GB containing $250 \mathrm{U}$ heparin and $5000 \mathrm{KIE}$ Trasy$10{ }^{\circledR}$. After centrifugation, the plasma was stored at $-25^{\circ} \mathrm{C}$. The samples were thawed at room temperature, mixed and centrifuged at $4^{\circ} \mathrm{C}$ just prior to the assay.

\section{Assay Procedure}

During the preparation of the assay, all reagents and reaction tubes were maintained in melting ice baths. Into the glass incubation tubes $(10 \times 55 \mathrm{~mm})$ were pipetted sequentially:

$-100 \mu$ l of standard solutions or unknown samples;

$-100 \mu l$ of either antiserum diluted (1/1200) in GA.

TRAS, or buffer GA-TRAS alone.

After $40 \mathrm{~h}$ of incubation at $4^{\circ} \mathrm{C}, 100 \mu \mathrm{l}{ }^{131} \mathrm{I}$-glucagon $(25 \mathrm{pg})$ were added for a second incubation of $72 \mathrm{~h}$ at $4^{\circ} \mathrm{C}$. The incubation times chosen enabled the system to reach equilibrium and provided the best slope of the standard curve. Triplicates were prepared for the standard solutions and their control containing neither unlabelled glucagon nor antiserum (blank); a set of tubes contained only the labelled glucagon (total radioactivity). Each unknown was assayed in duplicate with two blanks.

The standard and unknown incubation tubes were brought to the same final protein concentration by addition of $150 \mu l$ of cold human plasma, non-diluted and diluted 1/3 with buffer GB, respectively. Without delay, $0.5 \mathrm{ml}$ chilled PEG (12.5\% final concentration) was dispensed in all assay tubes, that were carefully shaken. This concentration of PEG was shown to ensure complete precipitation of antibody-bound hormone [8]. After $30 \mathrm{~min}$ incubation at $4^{\circ} \mathrm{C}$, the tubes were centrifuged at $4^{\circ} \mathrm{C}$ for $45 \mathrm{~min}$, at $1500 \times \mathrm{g}$. The supernatant was decanted and the tubes left upside down on soft paper in order to complete removal of the liquid phase. Radioactivity of the precipitate was then counted for $4 \mathrm{~min}$ in a well-type Automatic Gamma Analyser (Philips).

\section{Statistical Analysis}

Statistical analysis of the results was performed according to Snedecor and Cochran [31]. The results are given as the mean \pm estimate (s) of the standard deviation (S.D.) obtained from $\left.\mathrm{s}=\sqrt{[\Sigma}(\mathrm{x}-\overline{\mathrm{x}})^{2} /(\mathrm{n}-1)\right]$ when the number of determinations $(n)$ is greater than 2. Use is also made of the relationship $\left.s=\sqrt{[\Sigma} \mathrm{d}^{2} / 2 \mathrm{~N}\right]$, where $d$ is the difference between the two results in a duplicate determination, and $\mathrm{N}$ the number of duplicate determinations performed [30]. Calculation of $\mathrm{s}$ provides an evaluation of the extent to which repeated measurements of the same sample agree with their mean, in a single assay (precision) or in different assays (reproducibility). This evaluation is given by the coefficient of variation $C . \nabla .=\mathrm{s} / \overline{\mathrm{x}}$, expressed as a percentage of the mean $(\bar{x})$, or the fiducial range which estimates the limits inside which the real value is included. The fiducial range is derived from $M \pm t s / V \bar{n}$, where $\mathrm{M}$ is the mean of $\mathrm{n}$ determinations.

Whether two samples significantly differ from each other, and hence the least difference (d) required between two samples to be statistically different (quanti-

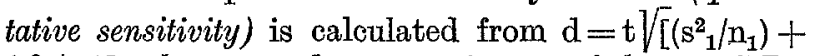
$\left.\left(\mathrm{s}_{2}{ }_{2} / \mathrm{n}_{2}\right)\right]$, where $\mathrm{s}_{1}$ and $\mathrm{s}_{2}$ are estimates of the two S.D., $n_{1}$ and $n_{2}$ the number of measurements in each case (i.e. 2 when the determinations are made in duplicate). Determination of the least value distinguishable from zero (qualitative sensitivity) is derived from $t s / \sqrt{\mathrm{n}}$, where $\mathrm{s}$ is the estimate of the S.D. made on $\mathrm{n}$ determinations. $t$ values used in these formulae are read at a level of significance $P=0.05$.

Statistical significance of differences between groups of samples was assessed by Student's $t$ test.

\section{Experimental Design}

Effect of Time and Protein Concentration Upon ${ }^{131} I$ Glucagon Precipitation by PEG. Series of tubes containing buffer or plasma samples, with or without antiserum, were run as described under "Assay procedure". The effect of time was studied by allowing variable delays to elapse between completion of $\mathrm{PEG}$ distribution and centrifugation. Meanwhile the tubes were kept at $4^{\circ} \mathrm{C}$. The effect of protein concentration was studied by adding various amounts of plasma before PEG precipitation.

Effect of Proteolytic Enzyme Inhibitors upon ${ }^{131} I$ Glucagon Degradation. To buffer or plasma samples were added buffer GA containing the inhibitor tested, and labelled glucagon, for incubation periods identical to those of the assay. The proportion of non degraded 131I-glucagon was estimated by precipitation with TCA. Standardization of protein content in each tube was carried out immediately before addition of cold TCA (final concentration $5 \%$, w/ $/$ ). After centrifugation and decantation, the radioactivity of the precipitate was counted. Blood samples utilized for this experiment were not taken into inhibitor. 
Evaluation of Precision, Sensitivity and Reproducibility of the Standard Curves. Eleven standard curves were performed over a six months period. For comparison of the different curves together, displacement of ${ }^{131}$ I-glucagon by unlabelled ghcagon was expressed in percentage of the precipitation recorded in the absence of unlabelled glucagon.

For each individual standard curve, the precision and quantitative sensitivity were calculated (see "Statistical Analysis") over each range of uniabelled glucagon addition. The individual values were finally pooled to provide the average C.V. $\pm \mathrm{s}$ and average sensitivities $\leq \mathrm{s}$.

Evaluation of Precision, Sensitivity and Reproducibility of the Assay when Applied to Plasma. C.V. of duplicate determinations of the blank $(4.28 \%$ for $600 \mathrm{cpm}$ during $4 \mathrm{~min} ; \mathrm{n}=50$ ) was not different from that of the counter $(4.33 \%$ for $500 \mathrm{cpm}$ during $4 \mathrm{~min}$; $\mathrm{n}=25$ ). The average blank was therefore substracted from each member of the duplicate measurement of the sample. ${ }^{1}$ The two values found served to caloulate precision and quantitative sensitivity as already described.

The reproducibility was evaluated by measuring glucagon concentration in 24 plasmas, taken at random, in two different assays. Some of these plasmas were thawed only once, whereas thawing of the others was repeated at the time of the two assays. The two glucagon concentrations found for each sample were compared by Student's $t$ test for paired data.

Recovery of Glucagon Added to Plasma. Solutions of unlabelled glucagon, with concentrations ranging from 0 to $5 \mathrm{ng} / \mathrm{ml}$ were prepared in buffer GB. To $900 \mu \mathrm{l}$ of several plasmas, containing $1000 \mathrm{KIE}$ Trasylol ${ }^{\circledR}$, were added $100 \mu \mathrm{l}$ of the different glucagon solutions. The glucagon concentration in these samples was measured as usual.

\section{Results and Discussion}

\section{Solubility of Free ${ }^{131} I$-Glucagon in $P E G$}

The solubility of ${ }^{131} \mathrm{I}$-glucagon in PEG concentrations ranging from 2.5 to $15 \%(\mathrm{w} / \mathrm{w})$ was studied in the conditions of the assay except for the absence of antiserum. The precipitation (mean $\pm \mathrm{s}, \mathrm{n}=10$ ), expressed as the percentage of total radioactivity, increased from $5.7 \pm 0.3 \%$ to $10.0 \pm 0.2 \%$ over the range of PEG concentrations studied.

Free glucagon, like growth hormone and parathyroid hormone [8] slightly coprecipitated with serum proteins, whereas insulin, vasopressin [8], and angiotensin I [6] remained virtually fully soluble as PEG concentration was increased.

1 For routine calculation of the results, the corresponding blank values were substracted from the counts given by each standard solution and unknown sample.

\section{Effect of Time between Addition of PEG and Centri- fugation}

As shown in Table 1, delaying centrifugation for as long as $90 \mathrm{~min}$ did not significantly modify the percentage of precipitated 131I-glucagon, whether the sample assayed was a plasma or a buffer.

Table 1. Effect of time between addition of PEG and centrifugation upon ${ }^{131} I$-glucagon precipitation

\begin{tabular}{clcc}
\hline Time (min) & Antiserum & Buffer sample & Plasma sample \\
\hline 0 & + & $34.6 \pm 0.1$ & $25.5 \pm 0.6^{\mathrm{b}}$ \\
& - & $9.4 \pm 0.4$ & $8.1 \pm 0.5$ \\
30 & + & $36.0 \pm 1.5$ & $27.0 \pm 0.7$ \\
& - & $9.5 \pm 0.1$ & $8.8 \pm 0.3$ \\
60 & + & $35.6 \pm 1.3$ & $26.1 \pm 1.0$ \\
& - & $9.4 \pm 0.4$ & $8.3 \pm 0.3$ \\
90 & + & $34.4 \pm 1.1$ & $26.3 \pm 0.9$ \\
& - & $8.5 \pm 0.3^{\mathrm{a}}$ & $8.8 \pm 0.2$ \\
\hline
\end{tabular}

Precipitation of 131I-glucagon by PEG is expressed in $\%$ of total radioactivity. Each value represents the mean $\pm \mathrm{s}$ (estimate of S.D.) of 5 determinations. Group a is statistically different $(p<0.01)$ from the corresponding ones at the three preceding times; group $b$ is significantly lower $(p<0.001)$ than the corresponding one at $\min 30$.

The absence of disturbance in the bound-free hormone equilibrium by PEG seems to be a characteristic of immunoassays using this polymer $[6,8]$. This is in contrast with separation techniques using particulate adsorbants, which require careful control of time exposure. Nonaka and Foa [26] reported indeed that adsorption of free glucagon by cellulose powder, for more than 5 min, rapidly decreased the amount of antibody-bound glucagon. In our assay procedure, a $30 \mathrm{~min}$ delay at $4^{\circ} \mathrm{C}$, starting at the completion of $\mathrm{PEG}$ distribution, was routinely adopted.

\section{Effect of the Protein Concentration upon PEG Pre- cipitation}

Immunoglobulins are almost totally precipitated with PEG [9] and their presence in the incubation medium is required in a sufficient concentration to ensure complete precipitation of antibody-bound hormones [8].

As illustrated in Fig. 1A, raising the volume of plasma added to buffer samples from 0 to $100 \mu \mathrm{in}$ duced a two-fold increase in ${ }^{131}$-glucagon precipitation in the presence of antibody. Higher volumes of plasma were much less efficient. As the volume of plasma was augmented, a slight increase of precipitated ${ }^{131}$ I-glucagon was also observed in the absence of antibody. In plasma samples (Fig. 1B), raising the protein content above $100 \mu \mathrm{l}$ progressively increased ${ }^{131} \mathrm{I}$-glucagon precipitation by $\mathrm{PEG}$, both in the presence and the absence of antiserum.

Yet, the precipitation due to antibodies remained fairly constant, provided a plasma volume of at least $100 \mu \mathrm{I}$ was present in the assay tubes, before PEG addition. Hence, the final plasma volume of all incubation tubes was brought to $150 \mu .1$ immediately before precipitation by PEG (see "Assay procedure"). 


\section{Effect of Proteolytic Enzymes Inhibitors upon ${ }^{131}$ I-Glucagon Degradation}

This series of experiments is based on the assumption that only undamaged ${ }^{131} \mathrm{I}$-glucagon is precipitable by TCA.

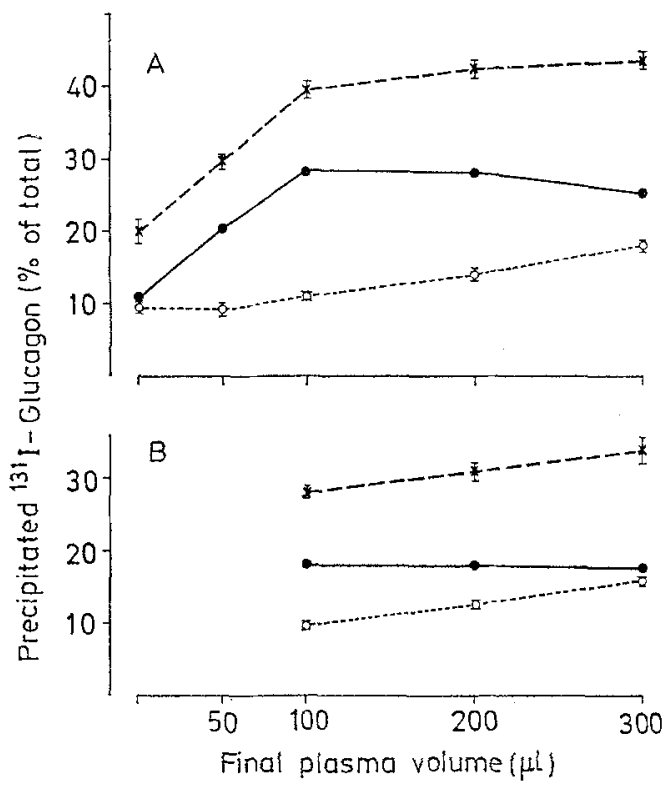

Fig. 1. Effect of protein concentration upon ${ }^{131} \mathrm{I}$-glucagon precipitation by $\mathrm{PEG}$. Increasing amounts of plasma were added immediately before PEG either to buffer $(A)$ or to plasma (B) samples $(100 \mu \mathrm{l})$ incubated with $(\mathrm{x} \ldots \ldots \ldots$..... $\mathrm{x})$ or without (0 . . . . . o) antiserum. The solid line (-) represents the precipitation due to antibodies; it is obtained from the difference between the two other lines. Each point is the mean $\pm \mathrm{s}$ (estimate of S.D.) of $\mathbf{5}$ determinations
Table 2 shows that after incubation in buffer, 92 to $93 \%{ }^{131} \mathrm{I}$-glucagon remained precipitable by TCA, whether the assay medium contained a proteolytic enzyme inhibitor or not. In contrast, after incubation with plasma, only $69 \%$ labelled glucagon were still precipitable. The presence of TrasyloI ${ }^{\circledR}(500 \mathrm{KIE} /$ tube $)$ almost completely prevented ${ }^{131} I$-glucagon degradation. Three concentrations of benzamidine tested $(5$, 10 and $16.5 \mathrm{mM}$ ) appeared to be nearly as efficient as Trasylol ${ }^{\circledR}$ alone. EACA, known to inhibit plasmin [1], showed a lower protective effect than that of the former drugs. The combination of Trasylol ${ }^{\circledR}(500 \mathrm{KIE} /$ tube $)$ and benzamidine $(5 \mathrm{mM})$ exhibited the greatest efficiency, totally preventing glucagon destruction by plasma.

The destruction of ${ }^{131}$ I-glucagon during incubation with human plasma, first reported by Mirsky et al. [24], is thought to be due to plasmin. The damage of labelled glucagon during immunoassay was recognized in 1963 [36] and suggested as a cause of erroneously high plas. ma glucagon values.

Eisentraut et al. [11] demonstrated that Trasylol ${ }^{\circledR}$, an inhibitor of kallikrein, plasmin, trypsin and chymotrypsin [33], efficiently prevented ${ }^{131}$ I-glucagon degradation during incubation. Other agents, such as mercaptoethanol, mercurophyllin [5], EDTA and $\mathrm{Mg}^{2+}$ [32], were also shown to be efficient. More recently, Ensinck et al. [12] suggested the use of benzamidine, a competitive inhibitor of plasmin, trypsin and thrombin [23] as a cheap substitute for Trasylol ${ }^{\circledR}$.

The efficiency of proteolytic enzymes inhibitors was studied in absence of antibodies as they protect ${ }^{131}$ I-glucagon by themselves [35]. Our results are in agreement with those of Eisentraut et al. [11] con-

Table 2. Effect of proteolytic enzymes inhibitors upon degradation of ${ }^{131}$ I-glucagon during incubation

\begin{tabular}{|c|c|c|c|c|c|c|c|c|}
\hline \multirow{2}{*}{$\begin{array}{l}\text { Line } \\
\text { No }\end{array}$} & \multirow[t]{2}{*}{ Inhibitor added } & \multirow[t]{2}{*}{ Concentration } & \multicolumn{6}{|c|}{ TCA precipitable radioactivity ( $\%$ of total) } \\
\hline & & & Buffer samples & $P$ & & Plasma samples & $P$ & \\
\hline 1 & $\mathrm{Nil}$ & - & $\begin{array}{l}92.9 \pm 3.9 \\
(65)\end{array}$ & & & $\begin{array}{l}68.9 \pm 8.9 \\
(92)\end{array}$ & & \\
\hline 2 & Trasylol ${ }^{\circledR}$ & $500 \mathrm{KIE} /$ tube & $\begin{array}{l}94.9 \pm 4.3 \\
(30)\end{array}$ & vs. 1 & $<0.05$ & $\begin{array}{l}87.9 \pm 5.2 \\
(74)\end{array}$ & $\begin{array}{l}\text { vs. B } \\
\text { vs. } 1\end{array}$ & $\begin{array}{l}<0.001 \\
<0.001\end{array}$ \\
\hline 3 & Benzamidine & $5 \mathrm{mM}$ & $\begin{array}{l}93.9 \pm 5.6 \\
(14)\end{array}$ & $\begin{array}{l}\text { vs. } 1 \\
\text { vs. } 2\end{array}$ & $\begin{array}{l}\text { N.S. } \\
\text { N.S. }\end{array}$ & $\begin{array}{l}85.8 \pm 3.4 \\
(26)\end{array}$ & $\begin{array}{l}\text { vs. B } \\
\text { vs. } 1 \\
\text { vs. } 2\end{array}$ & $\begin{array}{l}<0.001 \\
<0.001 \\
<0.02\end{array}$ \\
\hline 4 & Benzamidine & $10 \mathrm{mM}$ & $\begin{array}{l}93.1 \pm 4.7 \\
(14)\end{array}$ & $\begin{array}{l}\text { vs. } 1 \\
\text { vs. } 3\end{array}$ & $\begin{array}{l}\text { N.S. } \\
\text { N.S. }\end{array}$ & $\begin{array}{l}88.2 \pm 4.1 \\
(26)\end{array}$ & $\begin{array}{l}\text { Vs. B } \\
\text { Vs. } 1 \\
\text { Vs. } 3\end{array}$ & $\begin{array}{l}<0.005 \\
<0.001 \\
<0.05\end{array}$ \\
\hline$\tilde{5}$ & Benzamidine & $16.5 \mathrm{mM}$ & $\begin{array}{l}94.9 \pm 4.5 \\
(26)\end{array}$ & $\begin{array}{l}\text { vs. } 1 \\
\text { vs. } 3\end{array}$ & $\begin{array}{l}\text { N.S. } \\
\text { N.S. }\end{array}$ & $\begin{array}{l}89.3 \pm 4.0 \\
(60)\end{array}$ & $\begin{array}{l}\text { vs. } B \\
\text { vs. } 1 \\
\text { vs. } 4\end{array}$ & $\begin{array}{l}<0.001 \\
<0.001 \\
\text { N.S. }\end{array}$ \\
\hline 6 & EACA & $10 \mathrm{mM}$ & - & & & $\begin{array}{l}78.4 \pm 7.3 \\
(18)\end{array}$ & $\begin{array}{l}\text { vs. } 1 \\
\text { vs. } 2\end{array}$ & $\begin{array}{l}<0.001 \\
<0.001\end{array}$ \\
\hline 7 & $\begin{array}{l}\text { Trasylo1 }{ }^{\circledR}+ \\
\text { Benzamidine }\end{array}$ & $\begin{array}{l}500 \mathrm{KIE} / \text { tube } \\
5 \mathrm{mM}\end{array}$ & $\begin{array}{l}94.5 \pm 4.0 \\
(14)\end{array}$ & $\begin{array}{l}\text { vs. } 1 \\
\text { vs. } 2 \\
\text { vs. } 3\end{array}$ & $\begin{array}{l}\text { N.S. } \\
\text { N.S. } \\
\text { N.S. }\end{array}$ & $\begin{array}{l}93.3 \pm 2.7 \\
(14)\end{array}$ & $\begin{array}{l}\text { vs. B } \\
\text { vs. } 1 \\
\text { vs. } 2 \\
\text { vs. } 3\end{array}$ & $\begin{array}{l}\text { N.S. } \\
<0.001 \\
<0.001 \\
<0.001\end{array}$ \\
\hline
\end{tabular}

Results are expressed as the mean $\pm s$ (estimate of S.D.) of the number of samples shown in parentheses. Buffer samples were assayed singly and plasma samples in triplicate. vs. B refers to the statistical comparison between plasma and buffer samples on the same line. Comparison between two groups, in the same column, is indicated by vs. line No of the second group. N.S. means not significant. 
cerning Trasylol ${ }^{\circledR}$ protective role, with those of Assan et al. [5] regarding the poor effect of EACA and with those of Ensinck et al. [12] as to the use of benzamidine. Coincidence of standard curves performed in presence or absence of $5 \mathrm{mM}$ benzamidine (data not shown) ruled out a possible interference of the inhibitor with the antigen-antibody reaction. The same observation was made by Ensinck et al. [12] using Unger's 30K antiserum.

Henceforth $5 \mathrm{ml}$ blood samples are routinely collected into $50 \mu$ buffer $G B$, containing heparin and benzamidine, to achieve a concentration of respectively $15 \mathrm{U} / \mathrm{ml}$ and $7.5 \mathrm{mM}$ (to reach a final concentration of about $15 \mathrm{mM}$ in plasma, assuming a $50 \%$ hematocrit value). $500 \mathrm{KIE}$ Trasylol ${ }^{\circledR}$ are still added to each tube for the assay.

\section{Precision, Sensitivity and Reproducibility of the Standard Curves}

An estimate of the precision of standard curves is given in Table 3 . The average coefficient of variation remained lower than $3.2 \%$ up to $400 \mathrm{pg}$ unlabelled glu-

Table 3. Estimation of precision and sensitivity of standard curves for pure glucagon

\begin{tabular}{rlll}
\hline $\begin{array}{l}\text { Amount } \\
\text { of glu- } \\
\text { cagon } \\
\text { added } \\
\text { (pg/ml) }\end{array}$ & $\begin{array}{l}\text { Average C.V. } \\
(\%)\end{array}$ & $\begin{array}{l}\text { Average } \\
\text { quantitative } \\
\text { sensitivity over } \\
\text { given range } \\
\text { (pg/ml) }\end{array}$ & $\begin{array}{l}\text { Range } \\
\text { sensitivity } \\
\text { (pg/ml) }\end{array}$ \\
\hline 0 & $2.15 \pm 0.94$ & $23.7 \pm 9.6$ & $11-42$ \\
50 & $2.50 \pm 0.81$ & $21.6 \pm 5.9$ & $13-31$ \\
100 & $2.37 \pm 0.74$ & $33.0 \pm 10.5$ & $16-48$ \\
200 & $2.74 \pm 1.20$ & $51.3 \pm 10.2$ & $32-64$ \\
400 & $3.16 \pm 0.78$ & $86.6 \pm 34.8$ & $46-136$ \\
600 & $4.90 \pm 2.38$ & $179.6 \pm 67.3$ & $100-332$ \\
1000 & $7.12 \pm 3.06$ & $532.3 \pm 199.1$ & $200-930$ \\
2000 & $8.59 \pm 4.33$ & & \\
\hline
\end{tabular}

Results, calculated for 11 individual standard curves, are expressed as the mean $\pm \mathrm{s}$ (estimate of S.D.). For details in method of calculation, see section "Experimental design". eagon $/ \mathrm{ml}$. Differences of less than $25 \mathrm{pg} / \mathrm{ml}$ for glucagon concentrations lower than $100 \mathrm{pg} / \mathrm{ml}$ and of $33 \mathrm{pg} / \mathrm{ml}$ for concentrations between 100 and 200 $\mathrm{pg} / \mathrm{ml}$ could be discriminated with $95 \%$ confidence.

Comparison of the 11 standard curves performed during successive assays was hampered by the use of different ${ }^{131} \mathrm{I}$-glucagon batches. In these assays, the percentage of total ${ }^{131} I$-glucagon precipitated in the absence of unlabelled glucagon amounted to $38.1 \pm 9.7$ (mean $\pm \mathrm{s}$ (estimate of S.D.); range: 22.6 to $52.1 \%$ ). Fig. 2 demonstrates, however, a high reproducibility of the standard curves, when expressed as percentages of the radioactivity precipitated in absence of unlabelled glucagon. Furthermore, the slope of the curve was such that less than $40 \mathrm{pg}$ unlabelled glucagon $(400 \mathrm{pg} / \mathrm{ml})$ were sufficient to cause a $50 \%$ fall in labelled glucagon binding by the antiserum.

\section{Precision, Sensitivity and Reproducibility of the Assay when Applied to Plasma}

Estimation of precision and sensitivity was performed on 200 plasma samples taken at random and distributed over 5 ranges of glucagon content (Table 4).

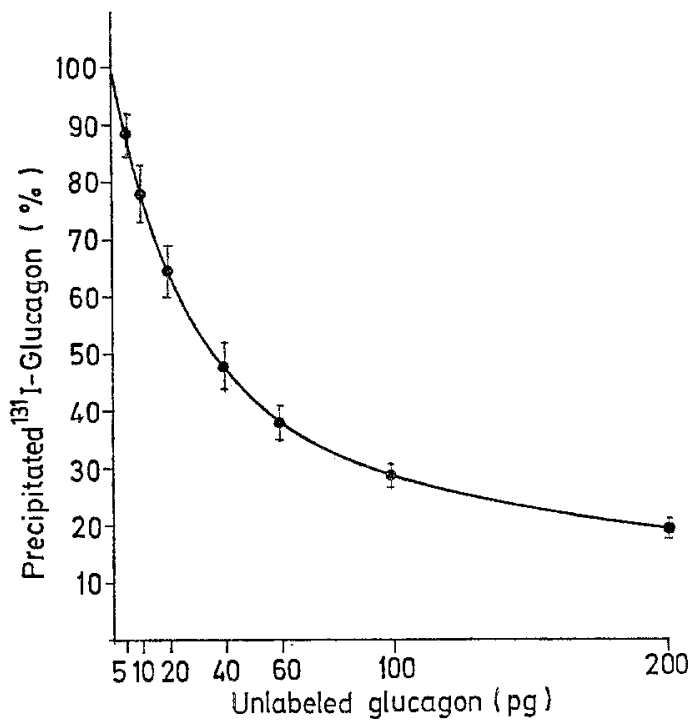

Fig. 2. Glucagon immunoassay standard curve. Each point represents the mean $\pm \mathrm{s}$ (estimate of S.D.) of 11 different assays

Table 4. Precision and sensitivity of the assay estimated by analysis of 200 duplicate determinations in plasma samples

\begin{tabular}{|c|c|c|c|c|c|}
\hline $\begin{array}{l}\text { Concentration range of } \\
\text { glucagon } \\
(\mathrm{pg} / \mathrm{ml})\end{array}$ & Mean $\pm \mathrm{s}$ & & C.V. & $\begin{array}{l}\mathrm{M} \pm \text { fiducial range } \mathrm{e}^{\mathrm{a}} \\
(\mathrm{pg} / \mathrm{ml})\end{array}$ & $\begin{array}{l}\text { Quantitative } \\
\text { sensitivity over } \\
\text { the range considered } \\
(\mathrm{pg} / \mathrm{ml})\end{array}$ \\
\hline $\begin{array}{r}<100 \\
100-150 \\
150-200 \\
200-300 \\
300-450\end{array}$ & $\begin{array}{r}71.0 \pm 11.9 \\
126.9 \pm 17.8 \\
177.1 \pm 18.7 \\
240.0 \pm 22.4 \\
347.7 \pm 24.5\end{array}$ & $\begin{array}{l}(32) \\
(74) \\
(47) \\
(35) \\
(12)\end{array}$ & $\begin{aligned} 16.8 \\
14.1 \\
10.5 \\
9.3 \\
7.0\end{aligned}$ & $\begin{array}{l}\mathrm{M} \pm 17.2 \\
\mathrm{M} \pm 25.2 \\
\mathrm{M} \pm 26.6 \\
\mathrm{M} \pm \mathbf{3 2 . 2} \\
\mathrm{M} \pm \mathbf{3 8 . 1}\end{array}$ & $\begin{array}{l}24.3 \\
35.6 \\
37.6 \\
45.6 \\
53.9\end{array}$ \\
\hline
\end{tabular}

The number of samples is indicated in parentheses. $s$ is an estimate of S.D.

a $\mathrm{M}$ is the mean of any duplicate determination; over each range of glucagon concentration, the fiducial range of $\mathrm{M}$ is calculated at a level of $\mathbf{9 5 \%}$ confidence (for details see "Statistical Analysis"). 
Plasmas, whose glucagon contents (ranging from 100 to $200 \mathrm{pg} / \mathrm{ml}$ ) differed from about $35 \mathrm{pg} / \mathrm{ml}$ could be distinguished from each other with $95 \%$ confidence.

This quantitative sensitivity was still greater for lower glucagon concentrations, and remained satisfactory for plasma glucagon contents above $300 \mathrm{pg} / \mathrm{ml}$. The qualitative sensitivity enabled us to distinguish a glucagon concentration of $17 \mathrm{pg} / \mathrm{ml}$ from zero.

The quantitative sensitivity of the assay in plasma was similar to that of the standard curve for purified glucagon (Table 3). The method and the antibody used provided a quantitative sensitivity (with $95 \%$ confidence) comparable with the best one recently report-

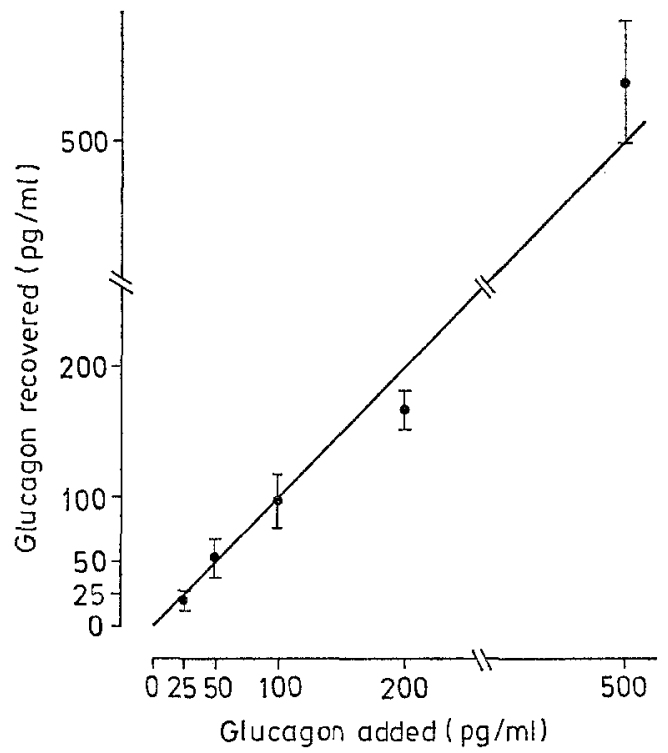

Fig. 3. Recovery of unlabelled glucagon added to plasma. Each point represents the mean $\pm s$ (estimate of S.D.) of 7 determinations

ed: $30 \mathrm{pg} / \mathrm{ml}[7,25]$; a qualitative sensitivity of $10 \mathrm{pg} /$ $\mathrm{ml}$ was mentioned by Iversen [18] and by Manns [22].

For the two assays involved in the study of reproducibility, the mean $\pm \mathrm{s}$ of the 24 determinations were: $156.5 \pm 38.7 \mathrm{pg} / \mathrm{ml}$ (range 110 to 280 ) and $154.4 \pm$ $41.0 \mathrm{pg} / \mathrm{ml}$ (range 95 to 220 ), respectively.

When considering, for each plasma, the glucagon concentrations measured by the two assays as members of a pair, the general mean $\pm \mathrm{s}$ was $155.4 \pm 14.8$ $\mathrm{pg} / \mathrm{ml}$ (for details in calculations, see "Statistical Analysis"). The C.V. of $9.5 \%$ observed was of the same importance as that expressing the precision in a single assay, for the same range of values (Table 4).

The reproducibility of our method can hardly be compared with others since few reports were made on that particular aspect of glucagon immunoassay, validity. However, Leclercq-Meyer et al. [20] reported a C.V. of $22.7 \%$ for a single human plasma $(211 \pm 48 \mathrm{pg} /$ $\mathrm{ml}$ ) assayed in 17 different runs and Heding [16] mentioned a C.V. of $8.9 \%$ for a gut extract (5.4 \pm 0.47 $\mathrm{ng} / \mathrm{ml}$ ) analyzed in 25 assays.
Glucagon concentrations (means $\pm s$ ) of the 9 plasmas thawed only once were $143.9 \pm 24.9 \mathrm{pg} / \mathrm{ml}$ and $146.1 \pm 48.4 \mathrm{pg} / \mathrm{ml}$ in the two assays. For the 15 plasmas thawed a second time after refreezing they were $164.0 \pm 44.1 \mathrm{pg} / \mathrm{ml}$ and $159.3 \pm 36.8 \mathrm{pg} / \mathrm{ml}$. These values were not statistically different. Thus thawing and refreezing the samples once did not seem to cause loss of glucagon immunoreactivity in plasma collected on Trasylol ${ }^{\circledR}$. A similar observation was made by Leclereq-Meyer et al. [20] with samples taken or not on Trasylol ${ }^{\circledR}$, which were thawed 4 times.

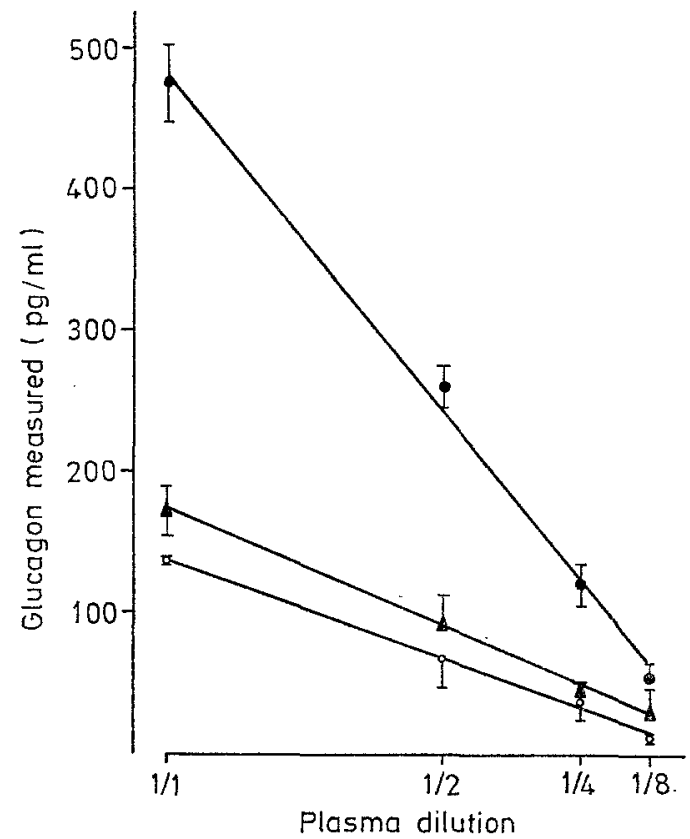

Fig. 4. Effect of dilution on apparent glucagon concentration in plasma. Each point represents the mean $\pm s$ (estimate of S.D.) of triplicate determinations

\section{Recovery of Glucagon Added to Plasma}

Fig. 3 shows the satisfactory recovery of exogenous glucagon added to different plasmas. The mean recoveries were $80,104,99,86$ and $109 \%$ respectively, for additions of $25,50,100,200$ and $500 \mathrm{pg}$ glucagon/ $\mathrm{ml}$. Only the $14 \%$ underestimation of the $200 \mathrm{pg}$ addition was significant $(p<0.005)$. Our results are comparable with recoveries reported by Hazzard et al. [15] for glucagon additions ranging from 100 to $2500 \mathrm{pg} /$ $250 \mu l$ and by Leclercq-Meyer et al. [20] for additions ranging from 250 to $5000 \mathrm{pg}$ glucagon $/ \mathrm{ml}$.

\section{Effect of Plasma Dilution upon Apparent Glucagon Concentration}

Fig. 4 illustrates that the experimental values fit well $(p<0.01)$ with the least square regression lines of measured glucagon concentrations on expected concentrations. From these results, it would seem that plasma constituents, and particularly gamma-globulins, do not interfere with glucagon measurement in our assay system. This is in contrast with previous reports 
$[4,37]$ suggesting that gamma-globulins are responsible for spuriously high plasma glucagon values measured in diluted samples, as compared with undiluted plasma. This interference could be overcome by extraction of glucagon with ethanol [16] or acetone [22].

A recent report by Weir et al. [39] suggested the existence of a factor, present in variable amounts in plasma from different individuals, which interferes with the binding of ${ }^{125}$ I-glucagon to Unger's antiserum 30K. As shown in Fig. 4, the linear relationship observed between dilution of three plasma samples (two fasting samples and one taken during an arginine infusion) and glucagon concentration indicated that, if such factor exists, it does not seem to affect the binding of labelled glucagon to antiserum K814.

In conclusion, the use of $\mathrm{PEG}$ to separate free and antibody-bound hormone led to the development of a sensitive and reproducible glucagon immunoassay. Its advantages over customary techniques make it easy and reliable for routine assay of large numbers of samples.

Acknowledgements. This work was supported by grant 20029 from the Fonds de la Recherche Scientifique Médicale, Brussels, Belgium. J.C.H. is Aspirant of the Fonds National de la Recherche Scientifique, Brussels, Belgium. We are indebted to Mrs. B. Debie-Horemans, Miss J Verniers and Mr. V.E. Decoster for slzilfull technical assistance and to Mrs. M. Verpoorten-Detaille for secretarial help. We gratefully acknowledge Dr. J. Schlicht. krull and Miss L.G. Heding (Novo Research Institute, Copenhagen, Denmark) for the donation of pure glucagon and anti-glucagon serum. Thanks are also due to $\mathrm{Mr}$. Wald (Bayer A.G., Leverkusen, Germany) for the generous gift of Trasylol and to Mr. J. Drouet (Centre National de Transfusion Sanguine, Paris, France) who kindly provided us with ${ }^{131}$ I-glucagon.

\section{References}

1. Ablondi, F.B., Hagan, J.J., Philips, M., Derenzo, E. C.: Inhibition of plasmin, trypsin and the streptokinase-activated fibrinolytic system by epsilonaminocaproic acid. Arch. Biochem. 82, 153-160 (1959)

2. Aguilar-Parada, E., Eisentraut, A.M., Unger, R.H.: Effects of starvation on plasma pancreatic glucagon in normal man. Diabetes 18, 717-723 (1969)

3. Assan, R., Rosselin, G., Dolais, J.: Effets sur la glucagonémie des perfusions et ingestions d'acides aminés. In: Journées annuelles de Diabétologie de l'Hôtel-Dieu, pp. 25-41. Paris: Ed. Médicales Flammarion 1967

4. Assan, R., Rosselin, G., Tchobroutsky, G., Freychet, P.: Dosage radioimmunologique du glucagon; application à l'étude d'extraits digestifs humains et animaux. Path. et Biol. 17, 45-51 (1969)

5. Assan, R., Tchobroutsky, G., Derot, M.: Glucagon radioimmunoassay: technical problems and recent data. Horm. Metab. Res. Suppl. Series 3, 82-90 (1971)

6. Barrett, M.J., Cohen, P.S.: Radioimmunoassay of serum renin activity and digoxin concentrations, with use of polyethylene glycol to separate free and antibody-bound ligand. Clin. Chem. 18, 1339-1342 (1972)

7. Bloom, S.R.: A specific and sensitive glucagon immunoassay. Diabetologia 7,472 (1971)
8. Desbuquois, B., Aurbach, G.D.: Use of polyethylene glycol to separate free and antibody-bound peptide hormones in radioimmunoassays. J. clin. Endocr. 33, $732-738$ (1971)

9. Desbuquois, B., Aurbach, G.D.: Distribution of free and antibody-bound peptide hormones in two-phase aqueous polymer systems. Biochem. J. 126, 717-726 (1972)

10. Edwards, J.C., Howell, S.L., Taylor, K.W.: Radioimmunoassay of glucagon released from isolated guinea-pig islets of Langerhans incubated in vitro. Biochim. biophys. Acta (Amst.) 215, $297-309$ (1970)

11. Eisentraut, A.M., Whissen, N., Unger, R.H.: Incubation damage in the radioimmunoassay for human plasma glucagon and its prevention with "Trasylol". Amer. J. med. Sci. 255, 137-142 (1968)

12. Ensinck, J.W., Shepard, C., Dudl, R.J., Williams, R. $H$.: Use of benzamidine as a proteolytic inhibitor in the radioimmunoassay of glucagon in plasma. J. clin. Endocr. 35, 463-467 (1972)

13. Gordon, P., Robertson, G.L., Beardwell, C., Klein, L. A., Roth, J.: Arginine Vasopressin (AVP): Radioimmunoassay in biological fluids in man. In: Hormones pancréatiques, hormones de l'eau et des électrolytes, pp. 511-520. Inserm 1972

14. Grodsky, G.M., Hayashida, T., Peng, C.T., Geschwind, T.I.: Production of glucagon antibodies and their role in metabolism and immunoassay of glu. eagon. Proc. Soc. exp. Biol. (N.Y.) 107, 491-494 (1961)

15. Hazzard, W.R., Crockford, P.M., Buchanan, K.D., Vance, J.E., Chen, R., Williams, R.H.: A double antibody immunoassay for glucagon. Diabetes 17, $179-186(1968)$

16. Heding, L.G.: Radioimmunological determination of pancreatic and gut gilucagon in plasma. Diabetologia $7,10-19(1971)$

17. Heding, L.G.: Radioimmunoassay of pancreatic and gut GLI. In: Hormones pancréatiques, hormones de l'eau et des électrolytes, pp. 239-258. Inserm 1972

18. Iversen, J.: Secretion of glucagon from the isolated, perfused canine pancreas. J. clin. Invest. 50, 21232136 (1971)

19. Lawrence, A.M.: Radioimmunoassayable glucagon levels in man : effects of starvation, hypoglycemia, and glucose administration. Proc. nat. Acad. Sci. (Wash.) $55,316-320(1966)$

20. Leclercq-Meyer, V., Mialhe, P., Malaisse, W.J.: Une méthode de dosage radioimmunologique du glucagon comportant une séparation par le charbon-dextran. Diabetologia 6, 121-129 (1970)

21. Luyckx, A. S.: Immunoassays for glucagon. In: Glucagon : Molecular physiology, Clinical and Therapeutic Implications, pp. 285-298 (Lefèbvre, P.J., Unger, R. H., Eds.). Oxford and New York: Pergamon Press 1972

22. Manns, J.G.: Separation of pancreatic and gut glucagon-like immunoreactivity (G.L.I.) with observations on plasma concentrations of these hormones during lactation. Canad. J. Physiol. Pharmacol. 50, $554-560(1972)$

23. Markwardt, F., Landmann, H., Walsmann, P.: Comparative studies on the inhibition of trypsin, plasmin, and thrombin by derivatives of benzylamine and benzamidine. Europ. J. Biochem. 6, 502-506 (1968)

24. Mirsky, I.A., Perisutti, G., Davis, N.C.: The destruction of glucagon by the blood plasma from various species. Endocrinology 64, 992-1001 (1959)

25. Muller, W.A., Faloona, G.R., Unger, R.H.: The influence of the antecedent diet upon glucagon and insulin secretion. New Engl. J. Med. 285, 1450-1454 (1971) 
26. Nonaka, K., Foa, P.P.: A simplified glucagon immunoassay and its use in a study of incubated pancreatic islets. Proc. Soc. exp. Biol. (N.Y.) 130, 330$336(1969)$

27. Orskov, H., Thomsen, H.G., Yde, H.: Wick-chromatography for rapid and reliable immunoassay of insulin, glucagon and growth hormone. Nature $\mathbf{2 1 9}$, $193-195$ (1968)

28. Rosselin, G., Broer, Y., Grapin, A.M.: Application de la méthode radioimmunologique au dosage des nucléotides. Dosage de l'AMP cyclique. In: Hormones pancréatiques, hormones de l'eau et des électrolytes, pp. 71-88. Inserm 1972

29. Shima, K., Foa, P.P.: A double antibody assay for glucagon. Clin. chim. Acta 22, 511-520 (1968)

30. Snedecor, G.W.: Query $n^{\circ} 92$. Biometrics 8, 85-86 (1952)

31. Snedecor, G. W., Cochran, W.G.: Statistical Methods. Sixth Edition. Ames, Iowa, U.S.A.: The Iowa State University Press 1967

32. Thomsen, H.G.: Pancreatic glucagon and "glucagonlike material" in the blood. Diabetologia 5, 430-431 (1969)

33. Trautschold, I., Werle, E., Zickgraf-Rüdel, G.: Trasylol. Biochem. Pharmacol. 16, 59-72 (1967)

34. Unger, R.H., Eisentraut, A.M., McCall, M.S., Keller,
S., Lanz, H.C., Madison, L.L.: Glucagon antibodies and their use for immunoassay for glucagon. Proc. Soc. exp. Biol. 102, 621-623 (1959)

35. Unger, R.H., Eisentraut, A.M., MeCall, M.S., Madison, L.L.: Glucagon antibodies and an immunoassay for glucagon. J. clin. Invest. 40, 1280-1289 (1961)

36. Unger, R.H., Eisentraut, A.M., Madison, L.L.: The effects of total starvation upon the levels of circulating glucagon and insulin in man. J. clin. Invest. 42, $1031-$ 1039 (1963)

37. Unger, R.H., Eisentraut, A.M.: Etudes récentes sur la physiologie du glucagon. In: Journées annuelles de Diabétologie de l'Hôtel-Dieu, pp. 7-18. Paris: Ed. Médicales Flammarion 1967

38. Weinges, K.F.: "Glucagon" in Biochemie und Klinik. Stuttgart: Georg Thieme Verlag 1966

39. Weir, G.C., Turner, R.C., Martin, D.B.: Glucagon radioimmunoassay using antiserum $30 \mathrm{~K}$ : Interference by plasma. Horm. Metab. Res. 5, 241-244 (1973)

Dr. Jean-Claude Henquin

Unité de Diabète et Croissance

Cliniques Universitaires St Pierre

69 , Brusselsestraat

B-3000 Louvain

Belgium 